\title{
Development of semantic processes for academic language in foundation phase EAL learners
}

\author{
Giselle Meirim \\ Heila Jordaan \\ Amy Kallenbach \\ Meera Rijhumal \\ Department of Speech Pathology and Audiology, School of Human and Community Development, University of the Witwatersrand, Johannesburg
}

Correspondence to: H Jordaan (Heila.jordaan@wits.ac.za)

\begin{abstract}
It is widely acknowledged that language competence is central to educational success, primarily because literacy is inherently a language-based activity. Vocabulary knowledge specifically plays an important role in the acquisition of reading comprehension skills. Language in education practice in South Africa is currently highly controversial, as the implementation of home language or bilingual instruction policies has not been achieved in many schools. The aim of this study was to investigate the development of language skills in foundation phase English Additional Language (EAL) learners attending schools where English is the language of learning and teaching. A 3-year longitudinal investigation of the acquisition of some of the processes underlying language for academic purposes was undertaken using the semantics subtests of the Developmental Evaluation of Language Variation Criterion Referenced Edition (Seymour, Roeper \& De Villiers, 2003). The results indicated that the majority of EAL learners improved with increased exposure to English in the academic environment and by the time they were in grade 3, were performing at a higher level than English First Language learners in grade 2. However, the effects of this protracted period of development on literacy attainment should be investigated. The significant individual variation in the learners' performance has implications for assessment and instruction of EAL learners and for the collaborative role of teachers and speech language therapists in the education system.
\end{abstract}

Keywords: academic language, EAL learners, foundation phase education, semantic development

The most significant issue for quality in education is 'the all pervasive and extremely powerful influence of language which is unambiguously implicated in learning ... and the need for pupils to have as good a grasp of the language of teaching and learning as possible' (Taylor, Muller \& Vinjevold, 2003, p. 65).

The purpose of this study was to track the development of some of the semantic processing skills underlying the development of English as the language of teaching and learning in grade 1 - 3 English Additional Language (EAL) learners. The rationale is based on the widely acknowledged fact that language competence and proficiency are central to educational success (Bashir, Conte \& Heerde, 1998; Hoff, 2005; Owens, 2008; Westby, 1994). One of the reasons for this is that literacy is inherently a language-based activity, rooted in well-developed oral language skills (Linan-Thompson \& Ortiz, 2009; Scarborough, 2001; Snow, Tabors \& Dickenson, 2001). This study focuses specifically on semantics, which deals with the expression and understanding of meaning and refers to the mental dictionary of words or the lexicon (De Villiers, 2004). Significantly, semantic knowledge plays an important role in the acquisition of early literacy and comprehension skills (LinanThompson \& Ortiz, 2009). Therefore, research on the acquisition of these language skills in the South African context is critical, since low levels of literacy are currently of serious concern (Howie, 2009; Kgosana, 2010; Tyobeka, 2006).

In education, language proficiency involves more than the ability to communicate in everyday conversational contexts, but is specifically related to the use of language for academic purposes. Cummins (2000, p. 67) defines academic language proficiency as '.... access to and command of the oral and written academic registers of schooling. Academic language proficiency is not acquired as naturally as basic interpersonal communication skills and develops through exposure to formal education (Cummins, 2000; Hoff, 2005). This implies that educators should facilitate this development with explicit teaching strategies addressing the language implicit in various learning areas.

The language skills that should be developed during the foundation phase and their importance for academic development have been well described (Hoff, 2005; McLaughlin, 1998; Owens, 2008). Those pertaining to semantics include: rapid growth in vocabulary and conceptualisation, growth in knowledge of word formation processes, and the increasing ability to learn new words from context, a skill known as fast mapping (Hoff, 2005). There is research to show that the acquisition of these skills can be facilitated through explicit teaching of vocabulary and assisting children to make use of context to acquire words (Maynard, Pullen \& Coyne, 2010). However, these skills may not be explicitly addressed because language for academic purposes as a distinct register is not always recognised. In addition, there is evidence to suggest that teachers in South Africa are not only unaware of their responsibility to meet the language-related needs of learners but also lack the methodological skills to promote effective learning of academic language because they have not had the necessary training (Mroz, 2006; O’Connor \& Geiger, 2009; Uys, van der Walt, van den Berg, \& Botha, 2007).

However, the most compelling reason for investigating academic language development in the South African education system is that many learners must accomplish this in a second/additional language. As a result of our political history and the socio-linguistic influences operating within the country and by extension in education, the second language is almost always English (Braam, 2004; De Klerk, 2002; De Wet, 2002; Ntshingila, 2006). EAL learners are effectively learning the language of instruction through the language of instruction (Cummins, 2000), which may have an impact on their academic development. Cummins (2000) has suggested that EAL learners acquire basic interpersonal communication skills (BICS) in about 2 years, while cognitive academic language (CALP) skills are acquired in a period of 4 - 9 years, depending on the quality of English instruction they receive.

Regarding the language of instruction, research conducted internationally (cited in Genesee, Paradis \& Crago, 2004, p. 168), as well as in South Africa (Heugh, 2000; MacDonald, 1990), has provided strong evidence to suggest that learners develop academic language proficiency more effectively in their home language or alternatively, in bilingual/ multilingual education, where teaching occurs in both the first and second languages. Education policies in South Africa strongly support the use of home language and/or bilingual instruction (e.g. Language in Education Policy (LiEP), 1997), but in reality, the implementation of these policies has been slow (Alexander, 2010; Beukes, 2008; Carstens, 2006; Kamwendo, 2006). Recently, there does seem to be a renewed will to implement home language instruction since the current Minister of 
Basic Education has announced that from 2011, the language chosen by the learner as the language of learning and teaching (LoLT) shall be taught as a subject, or as a first additional language, from grade 1 and not from grade 2, as is currently the case. The teaching of English would therefore occur alongside mother tongue instruction for those learners who choose English as the LoLT. English will subsequently not replace the home language in the early grades (Motshekga, 2010).

However, the implementation of home language instruction and teaching of English in the foundation phase does not in any way absolve teachers of the responsibility for facilitating the learning of academic language. The principles are applicable to the teaching of any language.

Reasons for the hitherto lack of implementation of the LiEP include: the majority of South African parents believe that English is the language of empowerment and aspire to have their children educated in English (Gules, 2005; Kgosana, 2006); insufficient resources have been made available to give effect to home language and/or bilingual instruction (Manyike, 2007; Pandor, 2005); but more importantly the marked heterogeneity in the language backgrounds of learners and teachers, particularly in Gauteng, results in the inevitable choice of English as the LoLT (Adler, 2001; Granville, Janks, Joseph, Mphalele, Ramani, Reed \& Watson, 1997; Webb, 2004). Table I reflects the heterogeneity in the language backgrounds of the grade 1 learners in the three schools participating in this study. These figures clearly show that the implementation of home language instruction would be problematic in this context. This raises an important question: how do foundation phase learners manage to acquire English for academic purposes? This study attempts to address this question, since there is limited research on the extent to which EAL learners acquire the processes underlying academic language, and there have been few attempts to record their progress in the development of these skills over time. The study aims to reveal specific aspects that should be taught in this phase of education and to provide guidelines for the training of educators. The findings may also contribute to an understanding of what can reasonably be expected from EAL learners in the foundation phase so as to formulate valid assessment standards for academic language.

Table I. Number and proportion of grade 1 learners speaking each language at three inner-city schools in Johannesburg, Gauteng

$\begin{array}{lll}\text { Sepedi } & 26 & 8.1 \% \\ \text { IsiZulu } & 135 & 42.06 \% \\ \text { Sesotho } & 25 & 7.79 \% \\ \text { Chinyarwanda } & 3 & 0.93 \% \\ \text { Setswana } & 24 & 7.48 \% \\ \text { Nyanja } & 5 & 1.56 \% \\ \text { SiSwati } & 1 & 0.31 \% \\ \text { Swahili } & 2 & 0.62 \% \\ \text { Tshivenda } & 8 & 2.49 \% \\ \text { Tshona } & 5 & 1.56 \% \\ \text { Xitsonga } & 8 & 2.49 \% \\ \text { French } & 29 & 9.03 \% \\ \text { Afrikaans } & 7 & 2.18 \% \\ \text { Portuguese } & 1 & 0.31 \% \\ \text { English } & 10 & 3.12 \% \\ \text { Malawian } & 1 & 0.31 \% \\ \text { IsiNdebele } & 2 & 0.62 \% \\ \text { Cameronian } & 1 & 0.31 \% \\ \text { IsiXhosa } & 22 & 6.85 \% \\ \text { Unknown } & 6 & 1.87 \% \\ \text { Total } & 321 & 100 \%\end{array}$

In this regard, the collaborative role of the classroom teacher and the speech-language therapist (SLT) is relevant. SLTs have an intimate knowledge of the nature, development and functions of oral and written language. The SLT may act as the school's 'language expert' (Owens, 2004), who assumes the roles of co-teacher and consultant, as well as direct service provider, and is fully integrated in the classroom. The SLT is uniquely qualified to assist the classroom teacher in assessing each child's level of functioning, analysing the language requirements of various curricular activities and materials, and developing intervention strategies. The SLT could thus be a valuable resource in developing the academic language skills of the learners. The results of this study provide support for this collaboration, which is currently largely lacking in the South African education system (O'Connor \& Geiger, 2009).

Typically, the evaluation of language is a difficult task, as language is multi-dimensional and not easily measured. Teachers tend to evaluate learners according to criteria based on the content of their language and not the processes that underlie language. In this study, the processes underlying vocabulary development were assessed using the semantic subtests of the Developmental Evaluation of Language Variation Criterion Referenced edition (DELV-CR) (Seymour, Roeper \& de Villiers, 2003). The DELV-CR is an individually administered diagnostic test designed to identify language disorders in 4 - 9-yearold children. Although it was constructed for use with children whose first and primary language is English and to identify language disorders in children regardless of whether they speak mainstream American English (MAE) or African American English (AAE), it was considered appropriate for use in the South African context for a number of reasons. First, it assesses the processes and properties of language that go beneath the surface structure to tap knowledge that is universal to all speakers of English. Second, its focus on critical aspects of academic language makes it particularly valuable for the purpose of this study. Third, it can be used with children aged $4.0-9.11$ years and is therefore appropriate for children in the foundation phase of education who are generally 6 - 10 years old.

The DELV-CR edition is the culmination of many years of research and conceptual advances in the areas of language acquisition and communication disorders. It was field tested on 10144 - 9-year-olds from working class backgrounds in all regions of North America. Sixty per cent of the sample were speakers of AAE and were matched for parental education level (high school and lower) to the mainstream American children in the sample. Approximately one-third of the children at each age and in each dialect group were language-impaired. Despite its American origin, the DELV is considered to be highly appropriate for assessing the development of language for academic purposes in any context, because it is specifically designed to capture many aspects of language that are important for success in early schooling and the transition to literacy (De Villiers, 2004). It provides a profile of strengths and weaknesses and therefore has implications for areas and methods of teaching and intervention.

\section{Method \\ Aim}

The main aim of the study was to determine how foundation-phase EAL learners acquire the semantic processing skills underlying language for academic purposes.

\section{Design}

The study falls within the quantitative, descriptive paradigm, and is longitudinal in nature. A longitudinal design is considered to be the most appropriate method of obtaining information on the process of language acquisition, which is dynamic and influenced by a number of variables, all of which can affect performance on a single measure (de Bot, Lowie \& Verschoor, 2005). Repeated measures over time are essential to obtain an accurate reflection of language abilities. The EAL learners were therefore followed up over a period of 2 years and withingroup comparisons of their performance in grades 1 and 2 and in grades 2 and 3 were conducted.

\section{Participants}

In consultation with the Gauteng Department of Education, participants were purposively selected from three schools in the inner-city area of Johannesburg East, Gauteng. When the study commenced, information sheets and consent forms were distributed to all the parents of grade 1 learners at each school, and those children whose parents gave 
informed consent for their participation were considered for inclusion in the study, provided they met the criteria for selection. The response rates at the three schools varied between $60 \%$ and $75 \%$.

The participants varied in socio-economic status, but were mainly from middle- to low-income families. The LoLT in all three schools was English, and the foundation phase teachers spoke English as either a first or additional language. All the learners at all three schools were EAL.

The sample size was initially 56 when the learners were in grade 1 but was reduced to 35 when the learners were in grade 3 , as a result of attrition. The learners were selected according to the following criteria:

- IsiZulu had to be their dominant first language, as it is the most widely spoken in South Africa, and is the most commonly spoken language in Gauteng (Statistics South Africa, 2001). Furthermore, the reason for choosing learners from only one language group was to restrict the influence of the first language on the results of the test.

- The learners were required to be developing typically in every respect including speech, language and hearing functioning. This was established from school records.

\section{Research instrument: semantic subtest of the Diagnos- tic Evaluation of Language Variation: Criterion-Refer- enced (DELV-CR)}

For the reasons outlined in the introduction, this test is considered to be an appropriate measure of academic language. The semantic subtest of the DELV-CR consists of the following three components:

\section{Verb and preposition contrast items}

The verb and preposition contrast items examine a child's vocabulary organisation (Seymour et al., 2003). The ability to organise words flexibly for efficient retrieval is a skill that develops throughout the school-age years (Aitchison, 1987). The DELV-CR assesses the organisation of verbs because they are less influenced by cultural variation than nouns; verb meanings are central to language development (Tomasello \& Merriman, 1995); and verb lexicons have been shown to be vulnerable in languageimpaired children (Rice \& Bode, 1993). Items on this subtest analyse the ability to provide suitable verb contrasts at the appropriate hierarchical level. The verbs examined in the DELV-CR include motion, grooming, breaking, corresponding, and dressing (Seymour et al., 2003). The child is required to provide verbs to complete a sentence about a picture, for example: 'The man isn't walking, he's ... crawling.'

Preposition organisation is also tested because there is a limited set and prepositions are less variable across different dialects of English. The preposition contrast items use the same structure as the verb contrast items. The purpose of this subtest is to examine the child's skills in producing spatial and grammatical prepositions that are in contrast to the ones used in the prompts (Seymour et al., 2003). The child is shown a picture, and is required to complete a sentence, for example: 'She's not looking at the radio, she's listening ... to the radio.'

\section{Quantifier items}

Quantification is based on the connection between word meaning and logic, is found in all languages and occurs frequently in the language of mathematics. The use of quantifiers provides insight into how well the child's developing grammar can manage the complex constructions that are used in everyday discourse (Seymour et al., 2003). This sub-test has eight components, three of which analyse the child's acquisition of the meaning of the quantifier 'every', as well as the understanding of the syntactic constraints that govern its production; another three items which examine the understanding that 'every' only affects the noun that follows it; and two which analyse the understanding of the syntactic constraints that regulate the production of 'every' across sentences (Seymour et al., 2003). The child is asked to point to pictures being spoken about, for example: 'Every man is riding a horse.'

\section{Fast-mapping items}

Fast mapping is a language skill found in all children regardless of cultural or linguistic background. Learning verbs in particular is highly dependent on understanding grammar and interpreting sentence context. It is also a skill that is required in the classroom when acquiring new vocabulary, and is therefore important for academic success. This component of the semantic sub-test examines the ability to derive the meaning of an unfamiliar word from the context it is used in, after a few exposures. The first group of items included in this sub-test, teaches the child the task by using real verbs in the prompt. The second group of items makes use of novel verbs. For each item, the child is provided with a series of three pictured episodes, while the administrator expresses an action (e.g. real verb: 'The boy is pouring juice. Novel verb: 'The girl is zanning the apple to the clown'). The child is then expected to respond to a number of questions about the characters and objects in the series of pictures, by pointing to one of four smaller pictures, using what he/ she understands about word order and word endings. The verbs used in this component consist of three variations: transitive verbs, transfer verbs and complements (Seymour et al., 2003).

\section{Procedure for data collection}

The participants were initially assessed at the end of grade 1 to ensure sufficient exposure to English to participate in the study. The second assessment was conducted towards the end of the grade 2 year and the third assessment at the end of the grade 3 year. Participants were assessed individually on the DELV-CR by the researchers who are experienced in language testing and familiar with the test procedure. This ensured a degree of reliability in the results obtained. The test was administered and scored according to the instructions in the manual. Although the participants were given verbal encouragement throughout the testing they were not given any indication of the correctness of their responses so that any changes observed over the 3-year period would not be due to learned knowledge of the test items.

\section{Ethical considerations}

The Ethics Committee for Research on Human Subjects, University of the Witwatersrand, approved the study (Protocol No.: H080404). Furthermore, approval was obtained from the Gauteng Department of Education (GDE) to conduct the research in an educational setting, and subsequently informed consent was obtained from the principals and teachers of the selected schools. Because participants in the study were under the age of 18, informed consent was obtained from their parents/ legal guardians. In addition, assent was obtained from the children concerned (Greig \& Taylor, 1999). The information sheets and consent forms included details regarding the general purpose of the study and the voluntary nature of participation in the study was emphasised. In addition, confidentiality and anonymity of responses and results was assured.

\section{Reliability and validity}

In the context of this study, it was considered important to establish the validity of the semantic subtest of the DELV-CR as a measure of academic language skills. Validity may be defined as the agreement between a measure and the quality it is believed to measure' (Kaplan, 1987, p. 254). A word definition task was administered to the learners in grade 3, and the results were correlated with the results obtained on the total semantics score of the DELV-CR. Snow (1990) states that word definitions are largely learned and practised at school and a word definition task is therefore considered to be reflective of academic language skill. Specifically, the oral vocabulary subtest of the Test of Language Development-Primary (TOLD-P) (Newcomer \& Hammil, 1985) was administered. This subtest consists of 20 items which assess the ability to provide oral definitions for common English words. The learner is required to provide a brief explanation, a synonym or two major characteristics (e.g. function and appearance) of the word. Each child's score was calculated on the basis of the percentage of correct answers obtained. A Pearson's correlation coefficient revealed a strong positive correlation between the scores on the two tests $[r=0.61$ with a 
$t$-stat (4.49) > critical value (1.6909), alpha level (0.05)], thus providing convergent evidence that the DELV-CR is a valid measure of academic semantic skills (Kaplan, 1987).

Reliability of the test results for each participant was established using a measure of inter-tester reliability. At each test session, approximately onethird of the children were assessed by two examiners at the same time, with one administering and both scoring the test. Since administration and scoring of the test was conducted according to instructions in the manual, $100 \%$ agreement between testers was obtained.

\section{Data analysis}

The performance of the learners on the five semantic subtests of the DELV-CR at each data collection period was compared using descriptive measures of central tendency (mean) and variability (range) as well as inferential statistics (Kaplan, 1987). Specifically, the Wilcoxon's matched pairs signed rank test was used to conduct a within-group comparison of scores obtained in grades 1,2 and 3. This non-parametric procedure was considered to be preferable to the parametric t-test because it does not make assumptions about the distribution of the data (Kaplan, 1987).

Item analyses were conducted by calculating the proportion of participants getting each item correct on each subtest. This provided a clearer indication of strengths and weaknesses in semantic processing skills.

\section{Results and discussion \\ Development of semantic processing skills}

The primary aim of the study was to track the semantic processing skills of EAL learners over 3 years, using the semantic subtest of the DELV-CR. The children from the three schools were treated as a single group since an analysis of variance (ANOVA) revealed no significant differences between the learners from the different schools at the grade 1 level $(\mathrm{F}=1.2 ; p=0.31)$. In addition, no significant difference was found for gender $(t=0.35 ; p=0.36)$, and thus the need to take gender differences into account was disregarded.

Fig. 1 illustrates the scores (in percentage) attained by the participants on each subtest of the semantics section of the DELV-CR over 3 years.

The results of the Wilcoxon signed rank test to determine whether there were statistically significant improvements from grades 1 to 3 , are reflected in Table II.

Statistically significant differences at the $1 \%$ level are indicated by an asterisk $\left(^{*}\right)$. The participants improved significantly from grades 1 to 2 on all measures except preposition contrasts and the fast mapping of novel verbs. They improved significantly on all measures from grades 2 to 3 . These results indicate that exposure to English in an academic setting, over 3 years, does in fact result in a significant improvement in the learners' ability to provide verb and preposition contrasts, to understand quantification, and to fast map novel and real verbs, all of which are important for academic purposes. This is a most encouraging finding, as it confirms that the EAL learners were able to acquire the oral language skills required for schooling over time and that they benefited from the instruction they were receiving. However, there may still be doubt over the scholastic effects of this protracted period of development. This is an important implication of these results, and future research should investigate the literacy attainment of these learners and their ability to cope with the language demands of the curriculum beyond the third grade.

The quantifier subtest seems to be an area of strength, in that the learners obtained an average of $63 \%$ in grade 1 , which improved to $71 \%$ in grade 2 and $82 \%$ in grade 3 . This may be because quantification is widely used in the language of mathematics, which we can assume the learners are exposed to in the numeracy learning area. This provides evidence for the benefit of explicit language instruction in the context of subject teaching (Clegg, 1996). The learners also did relatively well

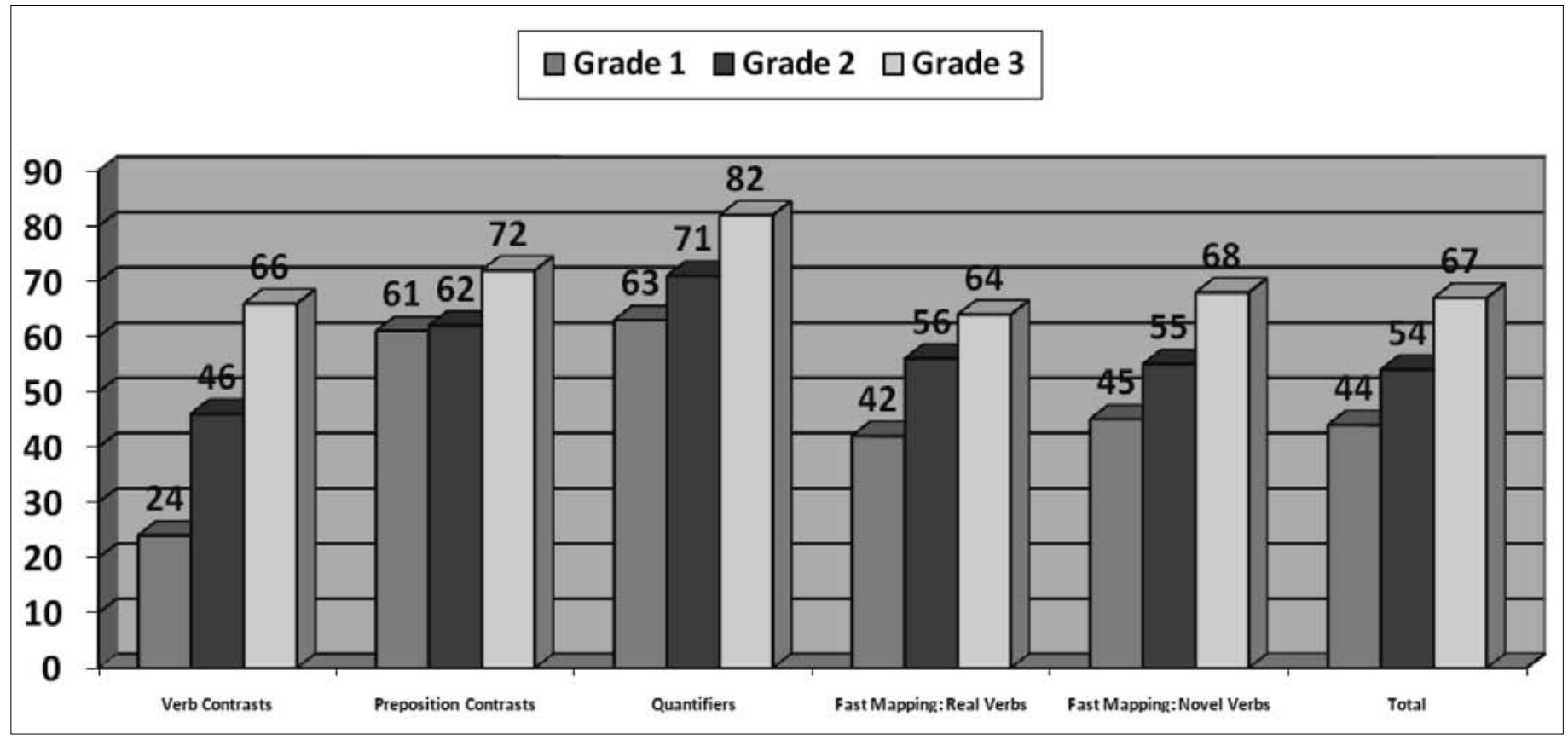

Fig.1. Mean scores (in \%) obtained by the EAL learners over a period of 3 years on the semantics subtest of the DELV-CR.

Table II. Statistical comparison of scores obtained in each grade on each subtest

\begin{tabular}{|c|c|c|c|c|c|c|c|c|c|c|c|c|}
\hline \multirow[t]{2}{*}{$\begin{array}{l}\text { Difference } \\
\text { between }\end{array}$} & \multicolumn{2}{|c|}{$\begin{array}{l}\text { Total semantics } \\
\text { score }\end{array}$} & \multicolumn{2}{|c|}{ Verb contrasts } & \multicolumn{2}{|c|}{$\begin{array}{c}\text { Preposition } \\
\text { contrasts } \\
\end{array}$} & \multicolumn{2}{|c|}{ Quantifiers } & \multicolumn{2}{|c|}{$\begin{array}{l}\text { Fast mapping: } \\
\text { real verbs }\end{array}$} & \multicolumn{2}{|c|}{$\begin{array}{c}\text { Fast mapping: } \\
\text { novel verbs }\end{array}$} \\
\hline & $\overline{z \text {-value }}$ & $p$-value & $\overline{z \text {-value }}$ & $p$-value & $\overline{z \text {-value }}$ & $p$-value & $z$-value & $p$-value & $\overline{z \text {-value }}$ & $p$-value & $z$-value & $p$-value \\
\hline & 4.913 & $0.000^{*}$ & 5.246 & $0.000^{*}$ & 0.726 & 0.468 & 3.692 & $0.000^{*}$ & 3.692 & $0.000^{*}$ & 0.309 & 0.757 \\
\hline Grade $2 \& 3$ & 30.972 & $0.00000^{*}$ & 6.583 & $0.00002^{*}$ & 4.33 & $0.01984^{*}$ & 7.388 & $0.00362^{*}$ & 5.777 & $0.00091^{*}$ & 6.888 & $0.00002^{*}$ \\
\hline
\end{tabular}


on providing preposition contrasts, with average scores of $61 \%$ and $62 \%$ in grades 1 and 2, and an improvement to $72 \%$ in grade 3 .

The greatest improvement was seen in the acquisition of the ability to provide verb contrasts, where the learners improved from an average of $24 \%$ in grade 1 to $46 \%$ in grade 2 and $66 \%$ in grade 3.

Verb and preposition contrast items assess vocabulary organisation. This is an important skill because no matter how different children's experiences and subsequent vocabulary are, the lexicon must be organised in a hierarchical pattern in order to efficiently retrieve words when needed (Capone \& McGregor, 2005; Seymour et al., 2003). Furthermore, adequate semantic networks are essential to reading comprehension, writing cohesion, retention and recall (Nicolosi, Harryman \& Kresheck, 1989). The EAL learners in this study have therefore made significant progress in their ability to organise their verb lexicon hierarchically, which would allow for easier retrieval and semantic networking, which in turn facilitates reading comprehension.

Fast mapping refers to the ability to guess the likely meaning of a new word after a few exposures (De Villiers, 2004). This skill is important for vocabulary learning (Seymour et al., 2003) and the ability to fast map novel words is particularly important to EAL learners in the academic environment, as they are continually exposed to new words representing academic concepts. The learners' fast-mapping skills improved significantly from an average of $46 \%$ in grade 1 to $55 \%$ in grade 2 to $68 \%$ in grade 3 .

\section{Individual variation in performance}

It should be noted that despite the generally positive results reported above, there is substantial individual variation in the scores obtained on each subtest (Table III), suggesting that there were children who did not do as well as the mean scores would suggest.

Table III shows that the range of scores (lowest to highest) within each subtest remains similar across the 3 years. The total score for the semantics section of the DELV-CR ranges from 24 to $41 / 50$ in the third year of the study. Paradis (2005) suggests that this wide variation in individual scores, which is more characteristic of second than first language acquisition, indicates that EAL children are acquiring English at varying individual rates, despite having similar language experiences. Although there are many affective, attitudinal, personality, social, situational and cognitive variables that may determine success in the language-learning situation (Baker, 1993), the variable that most consistently correlates with language-learning success is aptitude (de Bot et al., 2005). Language-learning aptitude is distinct from general intelligence and includes intrinsic skills such as the ability to: identify and remember sounds of the language; recognise how words function grammatically in sentences (lexical organisation); induce grammatical rules from the input; and recognise and remember words and phrases (fast mapping) (Carroll, 1981). De Bot et al. (2005) claim that recent approaches emphasise the information processing components of aptitude such as working memory and phonological memory. Phonological memory is assessed on non-word repetition tasks and is involved in the acquisition of vocabulary (Hoff, 2005). French and O'Brien (2008) and Hummel and French (2010) have shown that phonological memory in children plays a role in learning a second language in the classroom.

It is interesting that a different body of research reveals limitations in working memory capacity (Leonard, 2003; Maniela-Arnold \& Evans, 2005) and poor non-word repetition (phonological memory) skills (Botting \& Conti-Ramsden, 2001; Dollaghan \& Campbell, 1998; Ellis Weismer, Tomblin, Zhang, Chynoweth \& Jones, 2000; Tager-Flusberg \& Cooper, 1999) in children with language impairment. Further research on working memory and phonological memory in EAL children may enable one to distinguish those who are merely slow to learn from those who are language-impaired, and may enable one to identify those at risk for language impairment (Kohnert, Windsor \& Yim, 2006).

\section{Comparison with English first language (EFL) learners}

Although a comparison with EFL learners was not an explicit aim of this study, an interesting issue arising from these findings is the relative standing of the EAL participants in relation to a peer group. Any comparison with the American criterion group participating in the development of the DELV-CR would be problematic because of the different cultural environments and education systems in the USA and South Africa, but there are limited data available on the performance of South African children on the DELV-CR. One available study was conducted by Alborough (2007) on 42 grades 1 and 2 EFL learners in three schools in Johannesburg. A comparison between the mean scores obtained by the learners in this study with those obtained by the participants in the Alborough (2007) study is reflected in Figure 2. The actual scores are contained in Table IV.

Although statistical comparisons were not conducted, the graphs in Figure 2 and the values in Table IV suggest that the EAL learners did not perform as well as the EFL learners in grades 1 and 2, with large differences between them in grade 1 and slightly smaller differences between them in grade 2 . However, the grade 3 EAL learners were doing as well or outperforming the grade 2 EFL learners on all subtests except for the verb contrast items, suggesting that they may catch up to their EFL peers by grade 3. It is once again interesting to note that the EAL and EFL learners do not differ substantially on the preposition contrast or quantifier subtests, suggesting that where there is specific teaching of concepts in a subject area, such as mathematics, all children regardless of language background can learn the vocabulary of the curriculum. This phenomenon is discussed by Clegg (1996), who points out that

Table III. Means and range of raw scores in each grade for each subtest

\begin{tabular}{|c|c|c|c|c|c|c|c|}
\hline \multirow[b]{2}{*}{ Subtest } & \multirow[b]{2}{*}{ Total possible } & \multicolumn{3}{|c|}{ Mean scores } & \multicolumn{3}{|c|}{ Range of scores (lowest to highest) } \\
\hline & & Grade 1 & Grade 2 & Grade 3 & Grade 1 & Grade 2 & Grade 3 \\
\hline Verb contrasts & 10 & 2.4 & 4.31 & 6.58 & $0-7$ & $2-9$ & $3-10$ \\
\hline Preposition contrasts & 6 & 3.64 & 3.75 & 4.33 & $1-6$ & $1-6$ & $2-6$ \\
\hline Quantifiers & 9 & 5.7 & 6.6 & 7.38 & $3-9$ & $2-9$ & $5-9$ \\
\hline Fast mapping: real verbs & 10 & 3.64 & 4.87 & 5.77 & $1-7$ & $1-8$ & $4-8$ \\
\hline Fast mapping: novel verbs & 15 & 4.44 & 4.67 & 6.88 & $1-9$ & $1-11$ & $2-11$ \\
\hline Total & 50 & 19.69 & 24.2 & 30.97 & $12-32$ & $13-36$ & $24-41$ \\
\hline
\end{tabular}

Table IV. Comparison between mean scores (in \%) attained by EAL and EFL learners on each subtest

\begin{tabular}{|c|c|c|c|c|c|c|}
\hline & Verb contrast & Preposition contrast & Quantifiers & $\begin{array}{l}\text { Fast mapping: } \\
\text { real verbs }\end{array}$ & $\begin{array}{l}\text { Fast mapping: } \\
\text { novel verbs }\end{array}$ & Total score \\
\hline Grade 1 EAL & $24 \%$ & $60 \%$ & $63.33 \%$ & $36 \%$ & $29.33 \%$ & $39.4 \%$ \\
\hline Grade 1 EFL & $57 \%$ & $68.33 \%$ & $72.22 \%$ & $53 \%$ & $41.33 \%$ & $55.4 \%$ \\
\hline Grade 2 EFL & $71 \%$ & $66.67 \%$ & $72.22 \%$ & $57 \%$ & $41.33 \%$ & $59.2 \%$ \\
\hline Grade 2 EAL & $45 \%$ & $75 \%$ & $42.22 \%$ & $66 \%$ & $32.67 \%$ & $48.6 \%$ \\
\hline Grade 3 EAL & $65.8 \%$ & $72.22 \%$ & $82 \%$ & $57.7 \%$ & $45.87 \%$ & $62 \%$ \\
\hline
\end{tabular}




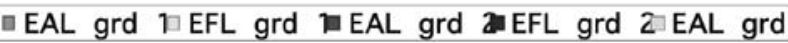

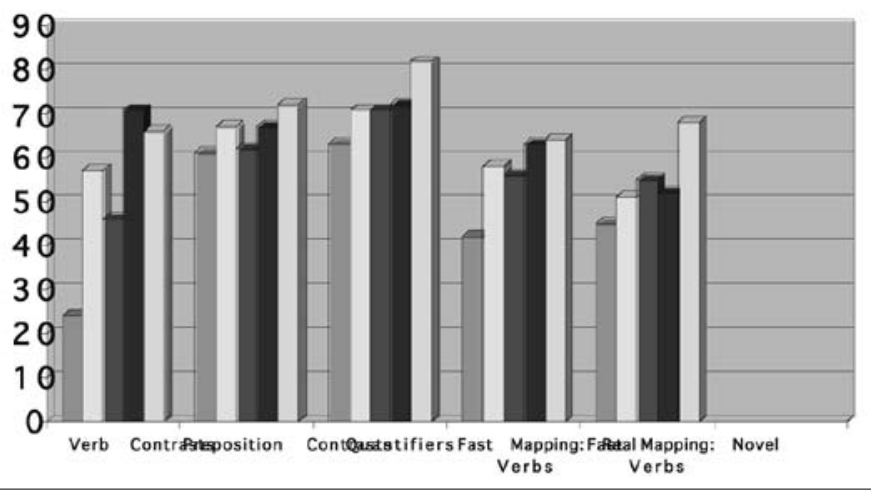

Fig. 2. Mean scores (in \%) obtained by the EAL learners from grades 1 to 3 and the EFL learners in grades 1 and 2 in Alborough (2007).

one of the benefits of instruction in an additional language is that there is concurrent learning of curriculum content and the language which is the vehicle for this. This is in contrast to the teaching of a language as a subject.

\section{Item analysis}

The results on individual items of the semantics subtests are examined in greater detail in Table V, which displays the proportion (in percentage) of participants getting each item correct on each subtest. The results were compared across the 3 years, in order to provide a clearer indication of areas of strength and weakness.

\section{Verb and preposition contrasts}

The results on the verb contrast subtest in the first 2 years indicate that the EAL children experienced difficulty in providing two different verbs for the same pictured scene. The percentage of correct responses for contrast 2 (e.g. 'The man isn't entering the building, he's ... going out') in both the first $(16.43 \%)$ and second $(32.89 \%$ ) year of exposure to English was significantly lower than that obtained for contrast 1 (e.g. 'The man isn't walking, he's ... crawling') (31.79\% and 58.22\%, respectively). However, after the third year of instruction in English, the difference between contrast 1 and 2 was reduced. These results suggest that over time the EAL learners increased their verb vocabulary, and were able to organise these verbs in a more structured manner in their lexicons (De Villiers, 2004).

The results on the preposition contrast subtest indicated that the EAL learners in the study were able to manage prepositions better than verbs, although they had more difficulty with abstract, grammatical prepositions (e.g. 'He's not climbing in the morning, he's climbing ... at night') than with spatial prepositions (e.g. 'She's not lifting the chair, she's sitting ... on the chair').

\section{Quantifiers}

The learners improved in their ability to understand the quantifier 'every' and that it only affects the noun that follows it (e.g. 'Is every dog eating a bone') ( $83.33 \%$ in the third year), as well as the conditions that regulate the production of 'every' across sentences (e.g. 'The boy saw every fish. He raised his eyebrows') (90.74\% in the third year). It can therefore be concluded that a good proportion of the EAL children in this study know the range of structures within which the word 'every' applies (Seymour et al., 2003). These results were consistent across all years, confirming that this area of language does not appear to be difficult for EAL learners and has been successfully developed in grade 3 .

\section{Fast mapping of real and novel verbs}

The results of this subtest showed that transitive verbs (e.g. 'The boy is pouring the juice. Which one was the pourer?') appear to pose a greater difficulty than transfer verbs (e.g. 'The postman is handing the letter to the boy. Which one got handed?') in both the real and novel verb fastmapping tests. Although the learners improved from $37.78 \%$ to $45.37 \%$ for real verbs in grades 1 and 2 and from $42.76 \%$ to $62.5 \%$ for novel verbs in grades 2 and 3 , they continue to experience difficulties in this area. With reference to real transfer verbs, a significant improvement was also noted over 3 years, as learners obtained $51.19 \%$ in grade 1 , followed by $74.07 \%$ and $82.40 \%$ in grade 2 and 3, respectively. Interestingly, although the EAL learners demonstrated an improvement in their ability to use novel transfer verbs over the 3 years, the difference in test scores was minimal (i.e. $55.36 \%$ in grade $1,58.67 \%$ in grade 2 , and $59.72 \%$ in grade 3 ). This minimal difference was also evident in the first 2 years with regard to complement verbs, where the test scores

Table V. Proportion of participants (in \%) getting each item correct on each subtest in each grade

\begin{tabular}{|c|c|c|c|c|c|c|}
\hline \multirow[b]{2}{*}{ Verb contrasts } & \multicolumn{2}{|c|}{ Grade 1} & \multicolumn{2}{|c|}{ Grade 2} & \multicolumn{2}{|c|}{ Grade 3} \\
\hline & Contrast 1 & Contrast 2 & Contrast 1 & Contrast 2 & Contrast 1 & Contrast 2 \\
\hline Motion & $41.07 \%$ & $12.50 \%$ & $77.78 \%$ & $33.33 \%$ & $91.66 \%$ & $72.22 \%$ \\
\hline Grooming & $44.64 \%$ & $5.36 \%$ & $77.78 \%$ & $8.89 \%$ & $94.44 \%$ & $33.3 \%$ \\
\hline Breaking & $16.07 \%$ & $33.92 \%$ & $35.56 \%$ & $51.11 \%$ & $38.88 \%$ & $86.11 \%$ \\
\hline Corresponding & $10.71 \%$ & $10.71 \%$ & $24.44 \%$ & $28.89 \%$ & $25 \%$ & $55.55 \%$ \\
\hline Dressing & $46.43 \%$ & $19.64 \%$ & $75.56 \%$ & $42.22 \%$ & $86.11 \%$ & $75 \%$ \\
\hline Overall total & $31.79 \%$ & $16.43 \%$ & $58.22 \%$ & $32.89 \%$ & $67.22 \%$ & $64.44 \%$ \\
\hline \multicolumn{7}{|l|}{ Preposition contrasts } \\
\hline Abstract/grammatical & $63.10 \%$ & & $55 \%$ & & $63.10 \%$ & \\
\hline Spatial & $58.33 \%$ & & $74.81 \%$ & & $89.81 \%$ & \\
\hline Overall total & $60.71 \%$ & & $62.22 \%$ & & $72.22 \%$ & \\
\hline \multicolumn{7}{|l|}{ Quantifiers } \\
\hline Meaning of 'every' & $56.94 \%$ & & $61 \%$ & & $75 \%$ & \\
\hline Scope of 'every' & $50 \%$ & & $82 \%$ & & $83.33 \%$ & \\
\hline Across sentence boundaries & $54.76 \%$ & & $62 \%$ & & $89.91 \%$ & \\
\hline Within sentence boundaries & $67.86 \%$ & & $81 \%$ & & $90.74 \%$ & \\
\hline Overall total & $63.01 \%$ & & $71 \%$ & & $82.09 \%$ & \\
\hline \multicolumn{7}{|l|}{ Fast mapping: real verbs } \\
\hline Transitive & $31.0 \%$ & & $37.78 \%$ & & $45.47 \%$ & \\
\hline Transfer & $51.19 \%$ & & $74.07 \%$ & & $82.40 \%$ & \\
\hline Complement & $46.63 \%$ & & $63.70 \%$ & & $64.81 \%$ & \\
\hline Overall total & $41.97 \%$ & & $56.44 \%$ & & $64.19 \%$ & \\
\hline \multicolumn{7}{|l|}{ Fast mapping: novel verbs } \\
\hline Transitive & $36.79 \%$ & & $42.67 \%$ & & $62.5 \%$ & \\
\hline Transfer & $55.36 \%$ & & $58.67 \%$ & & $59.72 \%$ & \\
\hline Complement & $36.79 \%$ & & $39.11 \%$ & & $50 \%$ & \\
\hline Overall total & $42.98 \%$ & & $46.81 \%$ & & $57.41 \%$ & \\
\hline Semantic total score & $44.75 \%$ & & $54.62 \%$ & & $67.73 \%$ & \\
\hline
\end{tabular}


were $36.79 \%$ (grade 1) and $39.11 \%$ (grade 2). Within the third year of exposure to English, however, the difference in test scores with regard to complement verbs improved from $39.11 \%$ to $50 \%$.

In general, the EAL learners performed progressively better on every verb type for both real and novel verbs, over a period of 3 years. However, the generally poor results obtained (with the exception of fast mapping of real transfer verbs), suggest that the learners experience difficulty in abstracting the meaning of verbs from the syntactic context of a sentence. Ultimately, this has implications for their academic achievement, as an inability to fast map new words effectively may hinder their ability to learn academic concepts. De Villiers (2004) suggests that the results from the fast-mapping items should be compared with the results from the verb-contrast items, in order to assess the ability to learn from linguistic context. This comparison indicated that the fast-mapping results in the third year of research $(64.19 \%$ for real verbs, $57.41 \%$ for novel verbs) corresponded within $5 \%$ with the verb-contrast results (65.83\%). These results reinforce the fact that the learners experience difficulty in acquiring English verbs merely from linguistic context. They may therefore benefit from explicit or direct teaching of English verbs and lexical organisation skills.

Roeper (2004) states that teachers should attempt to remove the ambiguities for EAL learners by establishing linguistic contexts that support and make these skills contextually clear. Vocabulary knowledge, according to Adamson (1993), is the most important aspect of oral English proficiency for academic achievement. He suggests that vocabulary taught to EAL learners should be explicit, and closely linked to the students' learning needs in their subject matter classes. Measures that are thought to be useful in making the classroom more accessible to these learners include common redundancy techniques such as repetition, explanation, giving examples, explicit boundary markers, visual supports, questioning and corrective feedback, and motivating learners to extend their utterances (Scarcella, 2009). SLTs have specialised knowledge of these techniques and can be employed effectively in the classroom to assist teachers.

\section{Conclusion}

This study has a few limitations which should be considered in the interpretation of the results. First, the investigation was limited to the assessment of semantic processing skills and excluded other equally important aspects of language processing such as pragmatics and syntax, which are also central to academic language. These processes are also assessed on the DELV-CR and should be included in further research to provide a more comprehensive picture of language development in the foundation phase. Second, participants were from a specific educational context in Johannesburg, Gauteng, where all the learners are EAL. This limits generalisability of the results to other contexts in which EAL and EFL learners are integrated in the same classes. The influence of different educational contexts can be investigated in future studies.

Despite these limitations, this study has highlighted both aspects that are cause for concern and positive aspects in the development of semantic processing and vocabulary acquisition skills by foundationphase EAL learners. While their significant improvement in these skills over the 3 years is positive, we do not know the consequences of such a protracted period of oral language acquisition for the development of literacy skills. This should be ascertained in future research studies. The children showing limited development over the 3 years suggest firstly, that not all EAL children acquire language skills as efficiently as others and secondly, that there are children with possible language-learning disabilities whose difficulties manifest in the additional language as a lack of progress in vocabulary acquisition and organisation skills. Further studies on information-processing abilities such as working memory and phonological memory may shed light on the underlying nature of these difficulties, as well as a possible aptitude for language learning among children learning through second languages in an academic context. The study confirms that there is an urgent need for establishing collaboration between teachers and SLTs in the education system so that language learning may be maximised. The fact that the learners showed better performance on those aspects, which we know are directly addressed through content teaching, further substantiates the basic premise that language skills can be successfully developed through explicit instruction. Specifically, this study highlighted the need for instruction in vocabulary acquisition and organisation, both of which are critical for reading comprehension and therefore literacy attainment.

Finally, some of the EAL learners in this study seem to exhibit weaknesses in verb learning, which parallel the difficulties experienced by children with language impairment (Paradis, Goldberg \& Crago, 2005). It is precisely this overlap that may lead to incorrect identification of EAL learners as language-impaired, but it also raises an important theoretical question: 'Is it not a particular vulnerability in the language, i.e. the English verb system, rather than a specific deficit in the learner that results in the observed difficulties in both EAL and impaired learners?' A positive response to this question has significant implications for the definition of language impairment as a specific deficit in the language faculty (Gopnik, 1990; Rice, 2003; Wexler, 2003). It is possible that language-learning skills are distributed on a continuum, and that those children labelled as 'language-impaired' are merely functioning at the lower end of the continuum. This matter warrants further investigation.

However, regardless of whether the problem is due to slow EAL learning or language impairment, intervention is critical since 'language is not everything in education, but without language, everything in education is nothing' (Wolff, in Alidou, Boly, Brock-Utne, Dallio, Heugh \& Wolff, 2006, p. 9).

\section{References}

Adamson, H. D. (1993). Academic competence. Theory and classroom practice: Preparing EAL students for content courses. New York: Longman.

Adler, J. (2001). Teaching mathematics in multilingual classrooms. Dordrecht: Kluwer Academic Publishers.

Aitchison, J. (1987). Words in the mind: An introduction to the mental lexicon. New York: Basil Blackwell.

Alborough, K. (2007). The application of the Diagnostic Evaluation of Language Variation (DELV) to monolingual English speaking grade ones and twos in South Africa. Unpublished Research Report, submitted in partial fulfilment of the requirements for the degree: B.A. (Speech and Hearing Therapy), University of the Witwatersrand, Johannesburg.

Alexander, N. (2010). Schooling in and for the New South Africa. Focus, 56, 7-13.

Alidou, H., Boly, A., Brock-Utne, B., Diallo, Y. S., Heugh, K., \& Wolff, H. E. (2006) Optimizing learning and education in Africa - the language factor. A stock-taking research on mother tongue and bilingual education in Sub-Saharan Africa. Paris: Association for the Development of Education in Africa (ADEA).

Baker, C. (1993). Foundation of bilingual education and bilingualism. Clevedon: Multilingual Matters.

Bashir, A. S., Conte, B. M., \& Heerde, S. M. (1998). Language and school success: collaborative challenges and choices. In D. D. Merritt \& B. Culatta (Eds.), Language Intervention in the classroom. San Diego: Singular Publishing Group.

Beukes, A. M. (2008). Language policy implementation in South Africa: How Kempton Park's great expectations are dashed in Tshwane. Stellenbosch Papers in Linguistics, 38, 1-26.

Botting, N., \& Conti-Ramsden, G. (2001). Non-word repetition and language development in children with specific language impairment (SLI). International Journal of Language and Communication Disorders, 36(4), 421-432.

Braam, D. (2004). Community perception of change in a school's language policy: PRAESA Occasional Papers No. 21. Cape Town: Project for the Study of Alternative Education in South Africa.

Capone, N. C., \& McGregor, K. K. (2005). The effect of semantic representation on toddlers' word retrieval. Journal of Speech, Language, and Hearing Research, 48(6), 1468-1481.

Carroll, J. B. (1981). Twenty five years of research on foreign language aptitude. In C. Diller (Ed.), Individual differences and universals in language learning. Rowley, MA: Newbury House.

Carstens, W. A. M. (2006). Praktiese meertaligheid - feit of fiksie? Journal for Language Teaching, 40(1), 1-19.

Clegg, J. (1996). Mainstreaming ESL. Clevedon: Multilingual Matters.

Cummins, J. (2000). Language, power and pedagogy: Bilingual children in the crossfire. Clevedon: Multilingual Matters.

De Bot, K., Lowie, W., \& Verschoor, M., (2005). Second language acquisition: An advanced resource book. London: Routledge Taylor \& Francis Group.

De Klerk, V. (2002). Language issues in our schools: Whose voice counts? Part 1: The parents speak. Perspective in Education, 20(1), 1-14.

De Villiers, J. G. (2004). Cultural and linguistic fairness in assessment of semantics. Seminars in Speech and Language, 25(1), 73-90.

De Wet, C. (2002). Factors influencing the choice of English as language of learning and teaching (LoLT) - a South African perspective. South African Journal of Education, 22(2), 119-124. 
Dolloghan, C., \& Campbell, T. (1998). Nonword repetition and child language impairment. Journal of Speech, Language and Hearing Research, 41, 1136-1146.

Ellis Weismer, S., Tomblin, J. B., Zhang, X., Chynoweth, J. G., \& Jones, M. (2000). Nonword repetition performance in school-age children with and without language impairment Journal of Speech, Language and Hearing Research, 43, 865-878.

French, L. M., \& O'Brien, I. (2008). Phonological memory and children's second language grammar learning. Applied Psycholinguistics, 29(3), 463-508.

Genesee, F., Paradis, J., \& Crago, M. B. (2004). Dual language development and disorders: A handbook on bilingualism and second language learning. Baltimore: Paul H. Brookes.

Gopnik, M. (1990). Feature blindness: A case study. Language Acquisition, 1, 139-164.

Granville, S., Janks, H., Joseph, M., Mphalele, M., Ramani, E., Reed, Y., \& Watson, P. (1997). English with without guilt: A position paper on language in education policy for South Africa. University of the Witwatersrand: Johannesburg.

Greig, A., \& Taylor, J. (1999). Doing research with children. London: Sage Publications.

Gules, N. (2005). The struggle for English. Sunday Times, 9 January.

Heugh, K. (2000). The case against bilingual and multilingual education in South Africa. PRAESA Occasional Papers No. 6. Cape Town: PRAESA (Project for the Study of Alternative Education in South Africa).

Hoff, E. (2005). Language development (3rd ed.). Wadsworth, UK: Thomson Learning.

Howie, S. (2009). The status of reading literacy in South Africa. primary school. Presented at the 2nd Annual THRASS Talk Together Conference, University of the Witwatersrand, Johannesburg.

Hummel, K. M., \& French, L. M. (2010). Phonological memory and implications for the second language classroom. The Canadian Modern Language Review, 66(3), 371-390.

Kamwendo. G. H. (2006). No easy walk to linguistic freedom: A critique of language planning during South Africa's first decade of democracy. Nordic Journal of African Studies, 15(1), 53-70

Kaplan, R. M. (1987). Basic statistics for the behavioural sciences. Boston: Allyn \& Bacon Inc.

Kgosana, C. (2006, 19 February). Moedertaal eerste? Liewer Engels, se sommige swart ouers. Rapport, p. 17.

Kgosana, C. (2010, 10 February). Basic education in crisis. The Star.

Kohnert, K., Windsor, J., \& Yim, D. (2006). Do language based processing tasks separate children with primary language impairment from typical bilinguals? Journal of Learning Disabilities Research and Practice, 21, 19-29.

Language in Education Policy. (1997). Pretoria: South African Department of National Education, Government Notice No. 282, Vol. 17997.

Leonard, L. B. (2003). Specific language impairment: Characterising the deficits. In Y. Levy \& J. Schaeffer (Eds.), Language competence across populations: Towards a definition of specific language impairment. Mahwah, NJ: Lawrence Erlbaum Associates.

Linan-Thompson, S., \& Ortiz, A. A. (2009). Response to intervention and English-language learners: Instructional and assessment considerations. Seminars in Speech and Language, 30, 105-120.

MacDonald, C. A. (1990). Crossing the threshold into standard three. Main report of the Threshold Project. Pretoria: Human Sciences Research Council.

Maniela-Arnold, E., \& Evans, J. L. (2005). Beyond capacity limitations: Determinants of word recall performance on verbal working memory span tasks in children with SLI. Journal of Speech, Language and Hearing Research, 48, 897-909.

Manyike, T. V. (2007). The acquisition of English academic language proficiency among grade 7 learners in South African schools. Unpublished Doctoral Thesis, University of South Africa.

Maynard, K. L., Pullen, P. C., \& Coyne, M. D. (2010). Teaching vocabulary to first-grade students through repeated shared storybook reading: A comparison of rich and basic instruction to incidental exposure. Literacy Research and Instruction, 49(3), 209-242.

McLaughlin, S. (1998). Introduction to language development. San Diego: Singular Publishing.

Motshekga, A. (2010, 6 July). Statement by Minister of Basic Education, Angie Motshekga, on the progress of the review of the National Curriculum Statement. Retrieved 12 August 2010 from http//:www.education.gov.za/statement

Mroz, M. (2006) Teaching in the foundation stage - how current systems support teachers' knowledge and understanding of children's speech and language. International Journal of Early Years Education, 14(1), 45-61.

Newcomer, P. L., \& Hammill, D. D. (1985). Test of language development. Primary. Texas: ProEd.

Nicolosi, L., Harryman, E., \& Kresheck, J. (1989). Terminology of communication disorders: Speech, language, hearing (3rd ed). Baltimore: Williams \& Wilkins.
Ntshingila, F. (2006, 28 May). Most speak Zulu at home, English at work, says survey: Warning that African languages face extinction. Sunday Times, p. 4.

O'Connor, J., \& Geiger, M. (2009). Challenges facing primary school educators of English second (or other) language learners in the Western Cape. South African Journal of Education, 29, 253-269.

Owens, R. E. (2004). Language disorders: A functional approach to assessment and intervention (4th ed). Boston: Pearson Education.

Owens, R. E. (2008). Language development: An introduction (7th ed.). Boston: Pearson Education.

Pandor, N. (2005, 5 October). Speaking Notes, Minister of Education, Naledi Pandor, at the Language Policy Implementation in HEIs Conference, UNISA, Pretoria. Retrieved 26 October 2006 from http://www.education.gov.za/dynamic.aspx?pageid=306\&id=2290

Paradis, J. (2005). Grammatical morphology in children learning English as a second language: implications of similarities with specific language impairment. Language, Speech and Hearing Services in Schools, 36(3), 172-187.

Paradis, J., Goldberg, H., \& Crago, M. (2005, March). Distinguishing between typically developing L2 children and children with SLI: Verb diversity and tense morphology over time. Poster presentation at International Symposium on Bilingualism, Barcelona, Spain.

Pressley, M., Levin, J. R., \& McDaniel, M. A. (1987). Remembering versus inferring what a word means: Mnemonic and contextual approaches. In M. G. Mckeown \& M. E. Curtis (Eds.), The Nature of Vocabulary Acquisition. Cambridge, MA: MIT Press.

Rice, M. K. (2003). A unified model of specific and general language delay: Grammatical tense as a clinical marker of unexpected variation. In Y. Levy \& J. Schaeffer (Eds.), Language competence across populations: Towards a definition of specific language impairment. Mahwah, NJ: Lawrence Erlbaum Associates.

Rice, M. L., \& Bode, J. V. (1993). Gaps in the verb lexicons of children with specific language impairment. First Language, 13, 113-131.

Roeper, T. (2004). Diagnosing language variation: Underlying principles for syntactic assessment. Seminars in Speech and Language, 25(1), 41-55.

Scarborough, H. S. (2001). Connecting early language and literacy to later reading abilities: Evidence, theory and practice. In S. Neuman \& D. K. Dickenson (Eds.), Handbook for research in early literacy. New York: Guilford Press.

Scarcella, R. (2009). Academic language for English language learners. Retrieved from http//:www.ColorinColorado.org

Seymour, H. N., Roeper, T. W., \& de Villiers, J. (2003). DELV Diagnostic Evaluation of Language Variation, Criterion Referenced: Examiners manual. Texas: Psychological Corporation, A Harcourt Assessment Company: United States of America.

Snow, C. E. (1990). The development of definitional skills. Journal of Child Language, 17, 697-

Snow, C. E., Tabors, P. O., \& Dickinson, D. K (2001). Language development in the preschool years. In D. K Dickinson \& P. O. Tabors (Eds.). Beginning literacy with language. Baltimore Paul H. Brookes.

Statistics South Africa (2001). Census 2001 Key Results.

Tager-Flusberg, H., \& Cooper, J. (1999). Present and future possibilities for defining a phenotype for specific language impairment. Journal of Speech, Language and Hearing Research, 42, 1275-1278.

Taylor, N., Muller, J., \& Vinjevold, P. (2003). Getting schools working: Research and systemic school reform in South Africa. Cape Town: Pearson Education South Africa.

Tomasello, M., \& Merriman, W. E. (Eds.) (1995). Beyond names for things: Young children's acquisition of verbs. Hillsdale, NJ: Lawrence Erlbaum Associates.

Tyobeka, P. T. (2006). An open letter to all primary school principals. Department of Education: Republic of South Africa.

Uys, M., Van der Walt, J., Van den Berg, R., \& Botha, S. (2007). English medium of instruction: A situational analysis. South African Journal of Education, 27(1), 69-82.

Webb, V. N. (2004). African languages as media of instruction in South Africa. Language Problems and Language Planning, 28(2), 147-173.

Westby, C. (1994). Communication refinement in school age and adolescence, In O. Haynes \& B. Shulman (Eds.), Communication development: Foundations, processes \& clinical applications (pp. 341-383). New Jersey: Prentice Hall.

Wexler, K. (2003). Lenneberg's dream: Learning, normal language development and specific language impairment. In Y. Levy \& J. Schaeffer (Eds.), Language competence across populations: Towards a definition of specific language impairment. Mahwah, NJ: Lawrence Erlbaum Associates. 